NBER WORKING PAPER SERIES

\title{
EXPECTED HOME OWNERSHIP AND REAL WEALTH ACCUMULATION OF YOUTH
}

\author{
Donald R. Haurin \\ Patric H. Hendershott \\ Susan M. Wachter
}

Working Paper 5629

\author{
NATIONAL BUREAU OF ECONOMIC RESEARCH \\ 1050 Massachusetts Avenue \\ Cambridge, MA 02138 \\ June 1996
}

We thank James Carr of Fannie Mae. Research assistance was supplied by Min Seok Yang. This paper is part of NBER's research program in Public Economics. Any opinions expressed are those of the authors and not those of the National Bureau of Economic Research.

(C) 1996 by Donald R. Haurin, Patric H. Hendershott and Susan M. Wachter. All rights reserved. Short sections of text, not to exceed two paragraphs, may be quoted without explicit permission provided that full credit, including () notice, is given to the source. 


\title{
EXPECTED HOME OWNERSHIP AND REAL WEALTH ACCUMULATION OF YOUTH
}

\begin{abstract}
This paper describes the real wealth accumulation of American youth and relates this behavior to variations in real constant-quality house prices in their localities of residence. We argue that increases in the real constant-quality house price have two offsetting effects on wealth. First, the greater the local constant-quality price of housing, the greater the wealth needed to meet the lender imposed down payment constraint if housing demand is price inelastic. However, increased real constant-quality house price reduces the likelihood of home ownership and thus the desire the accumulate wealth needed for a down payment.

Using a panel data set for youth age 20-33 for the years 1985 through 1990 we find that the combined direct and indirect impact of variations in real constant-quality house price on wealth is modest for changes near the average real house price, but youths' wealth declines substantially in areas with high real house price.

Donald R. Haurin

Department of Economics

Derby Hall

154 N Oval Mall

Ohio State University

Columbus, $\mathrm{OH} 43210$

Patrick H. Hendershott

Department of Finance

Hagerty Hall

1775 College Road

Ohio State University

Columbus, $\mathrm{OH} 43210$

and NBER

Susan M. Wachter

Finance Department

University of Pennsylvania

Philadelphia, PA 19104
\end{abstract}




\section{Introduction}

Many have argued that wealth is an important determinant of home ownership, largely owing to the down payment requirement of the secondary market and FHA (Jones 1989; Linneman and Wachter 1989; Zorn 1989). The less is wealth, the more binding is the constraint and the lower is home ownership. ${ }^{1}$ However, wealth of nonowning individuals is largely an endogenous variable, depending on their decisions about forming households, working hours, and saving earned income (Haurin, Hendershott, and Kim, 1994). ${ }^{2}$ Treating wealth as a determinant of home ownership puts the cart before the horse; more likely, it is the desire to become home owners that leads young individuals to accumulate wealth rather than wealth growth causing ownership. In fact, we are able to document a relation between wealth accumulation and the predicted home ownership rate, both concurrent and five years in the future.

We are especially interested in the role real house prices play in the link between wealth accumulation and the likelihood of home ownership. Because the price elasticity of housing quantity demand is less than unity in absolute value, ${ }^{3}$ the required down payment will be larger in areas with high real constant-quality house prices, and thus a household desiring to become an owner must accumulate more wealth in such areas. ${ }^{4}$ However, the higher is the real house price (relative to rents), the higher is the cost of owning relative to renting and thus the less attractive is home ownership. Moreover, the down payment constraint is more difficult to meet in these high cost areas, causing some young households choose to forego home ownership. The lower desired ownership in high price areas will reduce saving (Yoshikawa and Ohtake 1989; Engelhardt 1994; Sheiner 1995). The effect of higher real house prices on wealth accumulation is the net of less saving owing to fewer intended owners but greater saving by those with positive intentions.

The next section of the paper reviews studies that test the relationship between house prices and wealth. Then, we describe the primary data set, the National Longitudinal Survey of Youth (NLSY), and the secondary data set drawn from the repeat 
sales Freddie Mac/Fannie Mae constant-quality house price index. The descriptive analysis in Haurin, Hendershott, and Wachter (1995) is reviewed and selected relationships between wealth and house price are presented in section IV. In section V, the econometric model is described and estimation results are listed. Section VI highlights the interesting findings.

\section{Review of Studies on Wealth and the Tendency to Own a Home}

The paper by Yoshikawa and Ohtake (Y-O, 1989) explains female labor supply and household savings. They argue that utility maximizing renter households choose whether to pursue either a strategy of future renting or one where they will become home owners. Those who select the renter path will not be influenced by the constant-quality price of home ownership. They hypothesize that those planning to become owners will save more the higher is the price (especially in Japan where the down payment averages $40 \%$ of house value). ${ }^{5}$ However, an increase in the relative price of owning, resulting from higher real constant-quality house prices, decreases the tendency to own. ${ }^{6}$ Thus, higher house prices cause some potential owners to become permanent renters, lowering their savings, while those households remaining on the path to ownership increase their savings. The combined effect is ambiguous.

Their data include a variable indicating whether a household has a housing purchase plan (dichotomous). They first estimate a probit equation and find that a higher price of land reduces the number of households having a purchase plan. In separate selectivity bias corrected estimations of household savings rates on land prices, they find that those households who plan to own have a higher rate of savings if land prices rise, but those who plan to rent are unaffected. Among those with a purchase plan, the impact upon the savings rate of increased land prices is about zero when both the conditional impact and the tendency to switch desired tenure are accounted for. Among all renters, they find that increased land prices reduce the savings rate of households age 25-55. 
Questions about the study include the nature of the sample and the choice of explanatory variables used. Because the sample is limited to renters, households that successfully accumulate sufficient wealth to become owners are systematically excluded from the analysis. This elimination of "successful savers" may bias the estimation results. Turning to specific variables, the use of land price rather than constant-quality house price is a limitation. Also, they include current wealth in the ownership and savings rate estimations, failing to account for its endogeneity, and their estimation of the tendency to own (participation in a savings plan for ownership) excludes key variables such as the price of owning relative to renting.

Engelhardt (1994), using a Canadian data set, analyzes the relationship between saving for a down payment and constant-quality real house prices. The approach is similar to Yoshikawa and Ohtake: Canadian renters chose whether to participate in the Registered Home Ownership Savings Plan that provided a tax benefit to savings used for the purchase of a home. Some tax benefit accrues to participants even if they never intended to own due to the deferral of taxes, but other IRA-like programs were available as substitutes.

In the probit participation equation, Engelhardt finds that the higher is real house price, the lower is participation in the plan, but the effect is weak. ${ }^{7}$ Engelhardt then estimates selectivity bias corrected savings equations for participants and nonparticipants and finds no response to high house prices by nonparticipants (similar to Y-O). In contrast to $\mathrm{Y}-\mathrm{O}$, Engelhardt finds that savings fall as constant-quality house prices rise for participants, although the effect is only marginally significant. The combined effect is one of strong discouragement; high house prices reduce both the tendency to own a home and the rate of savings for those who plan to own. A weakness of this study includes its measure of house prices; only six Canadian regions adjusted for two categories of city size are included, and apparently house prices are not deflated by regional price indexes.

Further, the data are cross-sectional and are limited to renters. 
A third study by Sheiner (1995) finds that increased house prices lead to increased renter wealth. She used a 1984 cross section of the PSID in 26 U.S. metropolitan areas. For 25 to 34-year-old households, a $\$ 10,000$ increase in real house price yielded an increase in net worth of $\$ 400$.

All these studies have limited their observations to renters. This limitation is a concern because of the possibility of adverse selection of households who have not successfully saved for ownership. We report results for panel data that includes renters and home owners. The inclusion of owners requires us to adjust for their real wealth accumulation via real capital gains on housing and declines in the real value of their mortgage. ${ }^{8}$

These studies also employed cross-sectional data, which is a concern because prior research on wealth accumulation has shown that cross-sectional estimation can lead to biased results (Jianakoplos, Menchik, and Irvine 1989). Panel data allow us to use a richer model of the stochastic error structure, helping to compensate for omitted variables and to obtain unbiased estimates.

Finally, we focus on wealth rather than annual saving. Saving is smaller and subject to greater variation than is wealth; thus, identifying significant explanatory factors is more difficult. Also, down payments are in levels, not rates of change in wealth. Thus, households have a targeted amount of desired wealth based on desired house value.

\section{Model of Wealth Accumulation and the Tendency to Own a Home}

Two opposing economic forces affect the desire of middle and high permanent income renters to become owners. A positive force is the well-known U. S. tax advantage of home ownership for higher permanent income (tax bracket) households (Buser and Sanders 1983; Litzenberger and Sosin 1978), which provides an incentive to save and accumulate the required down payment. ${ }^{9}$ An opposing force is the intertemporal distortion in consumption of young households caused by saving to accumulate the down 
payment (Artle and Varaiya 1978). The greater is the cost of this distortion compared with the present value gain in tax benefits, the less likely a household will plan to be a home owner any time soon. The probability of ownership is a measure of the net impact of these forces. We hypothesize that the greater is this probability, the greater are savings, ceteris paribus.

Variations in constant-quality real house prices can affect the time to first home ownership. ${ }^{10}$ The higher are house prices relative to rents, the lower is desired home ownership. Also, higher real house prices will increase the down payment on the desired house (because the demand for housing is price inelastic) and thus the intertemporal distortion caused by saving for the down payment.

We first estimate the probability of home ownership as a reduced form equation including as explanatory variables exogenous socio-demographic and economic factors including the real price of housing, which should have a negative impact. This approach avoids the endogeneity problems inherent in the user cost approach to estimating the ownership equation. ${ }^{11}$

Next, we estimate a wealth accumulation equation including as explanatory variables the predicted probability of owning, real constant-quality house price, and a vector of socio-demographic controls. The expected coefficient of the probability of ownership is positive. Because the needed down payment varies with the expenditure on the house and this expenditure will rise or fall depending on whether the housing demand is inelastic or elastic, the sign of the coefficient of real constant-quality house price in the wealth equation could be positive or negative. However, because existing econometric evidence points to an inelastic demand, we expect a positive coefficient.

\section{Date Sources and Measurements}

The scope of this study requires a comprehensive data set containing variables descriptive of the economic/social/demographic characteristics of young households and 
indicators of local shelter costs. Our basic data set is the National Longitudinal Survey of Youth (NLSY), housed at the Center for Human Resource Research, Ohio State University. Beginning in 1979, a national survey of youth age 14-21 was administered to about 10,000 civilian respondents. The retention rate has been about $90 \%$ in subsequent years. Data are collected by personal survey except in 1987, which was collected by telephone (NLS Handbook 1993).

The NLSY sample is composed of a general sample and supplemental samples of blacks and poor whites. These supplements permit more reliable testing of hypotheses related to race/ethnicity and low income. Sample weights are provided each year, allowing statements to be made about the national population of youth. The NLS Handbook discusses details of the sampling methodology and survey design. Although the survey began in 1979, wealth data are reported only in broad categories before 1985, and no housing data were collected in 1991. Thus, our analysis of wealth accumulation is limited to the period $1985-1990$.

Supplemental data on constant-quality house prices are obtained for 388 counties in 101 metropolitan areas from the Freddie-Mac/Fannie-Mae repeat sales house price index. We match survey respondents' counties of residence to these data. ${ }^{12}$ Because these data are indexes, we need a single cross section of house price levels to obtain level data. We use the 1987 American Chamber of Commerce data (ACCRA 1987).

Nominal variables vary both over time and across space. We control for both by deflating using the panel data set of state deflators reported in McMahon (1991) covering $1985-1990 .{ }^{13}$ Other variables used in this study are derived from responses to survey questions in the NLSY (NLS Handbook 1993).

The wealth variable is the sum of net worth in five categories: housing, vehicles, other consumer durables, farm/business, and financial instruments. Within the housing category, an owner's estimate of both current house value and current mortgage debt are 
reported. In H-H-W (1995), we compared NLSY wealth data with those in the Survey of Consumer Finances and found good comparability in the two national samples. ${ }^{14}$

\section{Descriptive Results}

Table 1 presents the age-wealth relationship derived by H-H-W (1995). Reading across a row shows the increase in real wealth gained by households categorized by the 1985 age of the respondent. We find that real wealth increases rapidly; it takes about four years to triple at ages $20-23$ and double at ages $24-28$. The mean annual increase is $22 \%$, ranging from $8.1 \%$ in $1985-86$ to $33.3 \%$ in $1986-87$. This increase in household real wealth results from saving, capital gains, and marriage. ${ }^{15}$

Reading Table 1 southwest to northeast tracks the change in wealth of a particular age respondent across different years. The transcribed data (Table 2) reveal a modest decline in age-constant real wealth in 1986 , largely due to a decline in real farm prices. For ages 22-28, real wealth is greater for respondents of a particular age comparing the latest year data available to 1985 (the exception is age 27). This result suggests that the real wealth-age profile of young households was rising over the $1985-90$ period.

$\mathrm{H}-\mathrm{H}-\mathrm{W}$ find that wealth is related to many demographic variables including the respondent's gender, race/ethnicity, and marital status. The mean wealth of single female respondents is only $65 \%$ of male respondents. Single whites average about three and a half times more wealth than blacks. Married whites' wealth is nearly three times that of married blacks.

$\mathrm{H}-\mathrm{H}-\mathrm{W}$ also find that real wealth levels are related to two measures of human capital, highest grade completed and score on an analytical aptitude test. The results show that wealth rises with education except that the wealth of more highly educated but young respondents is low compared with less educated youth when the highly educated youth are still in school full time. The aptitude test measures age-adjusted abilities in mathematics 
and reading. The difference in wealth comparing highest to lowest quartile is dramatic (about $450 \%$ ).

\section{Home Ownership and Real Wealth}

Home ownership and real wealth are highly correlated. Table 3 (from H-H-W) presents the real wealth profile of eight groups of households including those who rented continuously during 1985-90, first time owners in each year 1986 to 1990 (five groups), those who owned prior to or became owners in 1985, and others (e.g., those few who switched from owning to renting). Two results are notable.

First, significant wealth accumulation occurs during the year of purchase of the house. Household wealth more than doubles for people becoming owners in all years except 1986 (50\% increase). One explanation for this is the correlation of first ownership with the year of marriage during which the wealth of two individuals is combined ( $9 \%$ of the sample married in the year they became a home owner). Wealth also increases by 33 percent on average in the year before first ownership, when $7 \%$ of the sample married). Another explanation for the jump in wealth during the year of purchasing a home is gifts or inheritances. $\mathrm{H}-\mathrm{H}-\mathrm{W}$ find that the percentage of households receiving these in the year of first home ownership is significantly greater than that received by renters or existing owners. The mean size gift is $\$ 5,224$, and of those households that received a gift and purchased a house in the years $1988-90$, the average value of the gift equaled $16 \%$ of the purchase price of their house. More than $60 \%$ of gifts received during the year of purchase were at least $5 \%$ of the values of the houses, and more owners continue to receive gifts/inheritances than do renters, suggesting a pattern of continuing parental support for a few years after first home ownership.

The second, and possibly most notable, result is that the wealth of nonowners is a good predictor of the timing of their future shift to home ownership. For example, households that became owners in 1990 had lower wealth in 1985 than did households that became owners in 1989. This relationship holds for all other combinations of years. 
Wealth increases across rows, comparing Owner-1990 with Owner-1989, . . , to Owner1985). Moreover, households that became owners in 1990 had greater wealth than did those renting in 1990 for at least the five prior years.

These results suggest that both marital status and the probability of becoming a home owner are important determinants of wealth. The relationship of wealth to future home ownership suggests that the probability of ownership is important to real wealth accumulation even at low probabilities and becomes quite strong at high probabilities. Real Wealth and Constant-Quality Real House Prices

The relationship between the real wealth of renters, partitioned by aptitude scores (and thus presumably permanent income), and real constant-quality house price is displayed in Table 4 (from H-H-W). For households with midlevel and high analytical aptitude scores, the data show a positive relation between wealth and constant-quality house price exists through the 75 th percentile, after which the relationship turns negative. For households with low test scores and thus presumably low permanent income and little incentive to own, there is no relation between wealth and constant-quality real house price. $^{16}$

\section{Econometric Model and Results}

The procedure consists of two steps: estimation of the probability of owning (current and five years forward), followed by the estimation of the wealth equation. Both estimations use the 1985-90 panel data and appropriate panel data estimation techniques.

\section{Probability of Current Ownership}

We assume that the tendency to own $\left(y_{i t}\right)$ is linearly related to a vector of exogenous socio-economic and demographic variables and a stochastic error consisting of a household specific component $\left(\mathrm{u}_{\mathrm{i}}\right)$ and a time varying component $\left(\mathrm{v}_{\mathrm{it}}\right)$ :

$$
y_{i t}=x_{i t} \beta+u_{i t}+v_{i t}=x_{i t} \beta+\varepsilon_{i t}
$$


Further, ownership (dichotomous) occurs if $y_{i t}$ exceeds a critical value (here, normalized to 0 ):

$$
\mathrm{O}_{\mathrm{it}}=1 \text { if } \mathrm{y}_{\mathrm{it}}>0 \text {, and }=0 \text { otherwise. }
$$

The "random effects" error structure assumes $\operatorname{var}\left(u_{i}+v_{i t}\right)=\sigma_{u}^{2}+\sigma_{v}^{2}$, and $\rho=\operatorname{corr}\left(\varepsilon_{i t}\right.$ $\left.\varepsilon_{i t+1}\right) .{ }^{17}$ The results of this estimation are used to predict a household's current tendency to own in each year of the panel.

Results of the reduced-form estimation of the probability of home ownership in the current year are presented in Table 5. Explanatory variables include indicators of whether the respondent is Male, Black, and Married. If married, the spouse's age and highest grade completed (HGC) are also relevant. Other variables are measures of the respondent's age, highest grade completed, and analytical aptitude, the locality's constantquality real house price and amount of gifts received. Quadratic terms for aptitude, house price, and respondent and spouse's age and HGC are included. Interaction terms with house price and Black are included to allow variations in house price to affect households differently.

The Chi-squared of this panel data probit estimation is quite significant as are most of the explanatory variables. The correlation coefficient ( $\rho$ from above) is 0.88 , indicating that estimation errors for a household persist over time; that is, the standard estimation approach would consistently over or under-predict the estimation residuals of a household from 1985-90. Of the 6324 observations (1054 households for six periods), the estimation correctly predicts 4288 of 4721 (90.8\%) cases of renting and 845 of $1603(52.7 \%)$ cases of owning. The sample mean predicted probability of owning is 0.20 , rising from roughly 0.12 in 1985 to 0.33 in 1990 .

Because of the complexity of the equation, simulation results are needed to clarify variables' impacts. For a white married male respondent, the probability of ownership is 0.46 at mean house price $(\$ 87,170)$ and at means of the other explanatory variables. ${ }^{18}$ The effect of variations in Hprice on the current estimated probability of owning is 
nonlinear. If Hprice is one standard deviation below its mean (s.d. $=\$ 21,974$ ), ownership probability remains about the same. At one standard deviation above the mean constantquality house price, the probability falls to 0.40 (a 11 percent drop), and at two standard deviations above the mean, the ownership probability falls to 0.31 (another 22 percent drop). ${ }^{19}$

The probability of ownership is much lower for black respondents even if evaluated at the same sample means of the explanatory variables. At mean Hprice, the ownership probability is 0.18 . At one standard deviation below the mean, the probability of ownership rises slightly to 0.19 , while at one and two standard deviations above the mean, the ownership probability for black households falls to 0.15 and 0.10 .

Marriage has an enormous impact as we expected. Marriage to a high school graduate age 26 increases the probability of ownership for a white youth from 0.13 to 0.46. Age also has a large impact on the probability of ownership. For a youth and spouse, an increase in age from 26 to 32 raises the probability of ownership from 0.46 to 0.83 .

\section{Probability that Current Renters Will Own in Five Years}

A similar method is used to estimate the probability that 1985 renters will be owners in 1990. The sample consists of all respondents because exclusion of current owners would result in selection bias. ${ }^{20}$ The dependent variable is the actual 1990 ownership status. Explanatory variables include 1985 socio-demographic variables (with age updated five years) except gifts/inheritances and marital status, both being forecasts of the 1990 outcome. ${ }^{21}$ We also control for current ownership status by including the 1985 probability of ownership in the equation. With a sample size of $1064,89 \%$ of instances of future renting are correctly predicted and $47 \%$ of future ownership (results are presented in Appendix 2). We use the estimation results to predict future ownership for the 1985-90 panel; that is, ownership rates in 1990-95. 


\section{Real Wealth}

The second step estimates the structural real wealth equation. In general, wealth accumulation is presumed to depend on liquidity, retirement, and bequest motives. For many young households, purchasing a home is the start of their retirement plan.

In this study, we highlight the impacts of variation in the probability of owning and in real local house prices on real wealth $\left(W_{l}\right)$. The econometric model again uses the random effects approach:

$$
\mathrm{W}_{\mathrm{t}}=\mathrm{z}_{\mathrm{il}} \alpha+\mu_{\mathrm{i}}+v_{\mathrm{it}}
$$

where $\mathrm{E}\left(\mu_{\mathrm{i}}\right)=\mathrm{E}\left(v_{\mathrm{it}}\right)=0$, and $\rho^{\mathrm{w}}=\operatorname{corr}\left(\mu_{\mathrm{i}}+v_{\mathrm{it}}, \mu_{\mathrm{i}}+v_{\mathrm{it}+1}\right)$. We also allow the $v_{\mathrm{it}}$ error term to be autocorrelated; thus, $v_{i t+1}=\rho_{i} v_{i t}+\eta_{i t .}^{22}$ Explanatory variables include demographic indicators: Male, Black, Squared Age, Married, Spouse Age, and a variable SumMarry measuring the total number of years married during the sample period ${ }^{23}$ Educational attainment measures include four variables: HGC, Spouse HGC, Aptitude, and Squared Aptitude. We also include a Squared Age-HGC interaction because of the likely delayed increase in wealth for respondents achieving post baccalaureate education. Each of these variables indicates the status of the respondent in year $t$ corresponding to wealth in that year.

One of the focal variables is the probability of home ownership predicted in the first step of the procedure. We expect that the greater this probability, the greater the need for early wealth accumulation for a down payment, default insurance fees and closing costs. $^{24}$ To allow for a nonlinear response of real wealth to variations in Probown, we include its square. Preliminary testing revealed that only the squared term was significant. We also include the probability of ownership five years in the future (Probown5) to capture the impact of future ownership tendencies on current wealth accumulation.

The other highlighted variable is local real house price, Hprice. Variations in constant-quality real house price affect wealth indirectly through the squared Probown and Probown5 variables (reduce the probability when Hprice rises) and directly by changing 
the quantity of housing demanded and the needed down payment. The quantity of housing demanded by a household depends negatively on the real constant-quality house price in the locality, but the down payment depends on the expenditure on the house; that is, the product of Hprice and housing quantity. Thus, variations in expenditure with Hprice depend on the price elasticity of demand of owned housing; if less than unity, we expect increased Hprice to raise expenditures on housing and thus the needed down payment. We test for separate impact of Hprice on black and other youth because the price elasticity of demand may differ among groups.

Another economic variable is the cumulative amount of gifts received by the household. This variable was hypothesized to be important to the growth of wealth during the preownership period by Mayer and Englehardt (1994) and was found to be an important component of the down payment by Haurin, Hendershott, and Wachter (1995).

Because our sample contains both renters (4380 observations) and owners (282 first time owners and 1662 post first year owners), we must account for any exogenous gains in real wealth accruing to owners. Because we have owner estimates of the house value, we can measure housing capital gains. Yearly gains are deflated and cumulated to year $t$ from 1985 or the year of first ownership yielding Capgain. We expect a coefficient somewhat less than unity because households have time (three years on average) to increase consumption in response to real housing capital gains, as predicted by intertemporal utility optimization.

We also created a variable that measures the difference between cumulated nominal housing capital housing gains and the real gain (Diffgain). If the down payment constraint were binding, then it is likely that a nominal capital gain would lead youth to reduce equity in the house and move consumption closer to the optimal path. This "consumption rebound" is predicted by the models of Artle and Varaiya (1978) and Engelhardt (1994). We expect a coefficient between zero and minus unity. 
Lastly, we include the cumulative change in the real book value of a household's mortgage. Over time, home owners pay down their mortgage and its real value declines due to inflation. We control for this change in real wealth by home owners, which we view as forced saving, expecting a coefficient between 0 and $-1.0 .^{25}$

Estimation results are reported in the first panel of Table 6 . The adjusted $R^{2}$ is 0.39 . The correlation of household residuals is 0.50 , and a Lagrange Multiplier test of the estimated random effects model compared with a simple pooled data model (no household specific error component) yields a value of 4415 , which is significant at the 0.001 level. The estimated autocorrelation of the it error terms is only 0.05 . We conclude that use of panel data techniques for this estimation is necessary. Further, the magnitude of many coefficients changes by more than 50 percent comparing the random effects model with simple pooled data OLS results (see the second panel of Table 6).

In the initial estimation, we find that the coefficient of Diffgain is -1.41 , significantly different from 0 but not from $-1,0$. Because the point estimate of -1.41 is implausibly large, in subsequent estimation we restricted the coefficient to equal -1.0 . This restriction does not affect the other regression coefficients.

The probability of ownership is an important determinant of real wealth accumulation of youth. The quadratic term (Squared Probown) is quite significant, suggesting that household saving surges the nearer is the transition to ownership. Also, the coefficient of the ownership probability in five years is positive and significant. An increase in the current probability of owning from 0.1 to 0.2 raises real wealth by $\$ 580$, measured at the means of the other explanatory variables and holding the future probability of owning constant. Further increases in Probown to 0.3 and 0.4 raise wealth by an additional $\$ 960$ and $\$ 1,350$. A dramatic comparison of impacts on wealth contrasts a household with current and future probabilities of owning of 0.2 and 0.5 to one with values of 0.7 and 0.9 , respectively. The estimated difference in real wealth is $\$ 10,400$, nearly equal to average wealth in the sample. 
The impact of increased Hprice on real wealth occurs directly and through the indirect effect on Probown and Probown5. The direct effect is positive and significant for nonblack households. A one standard-deviation increase in Hprice raises real wealth by $\$ 820$ or about $4 \%$ of the increase in constant-quality house price. This evidence is consistent with an inelastic housing demand. The result for black households differs. The sum of the coefficients of Hprice and Hprice*Black is not statistically different from 0; thus, black households do not increase their wealth if house price rises (Probown and Probown5 held constant). ${ }^{26}$

Increased Hprice lowers both Probown and Probown 5. This effect tends to reduce wealth, offsetting the direct positive effect of Hprice on the required down payment. For white households, wealth peaks just below the sample mean Hprice. As Hprice continues to rise the marginal impact of the direct down payment effect remains constant but the discouragement effect grows. The result is an inverse- $\mathrm{U}$ effect on wealth. ${ }^{27}$ For black households, there is no direct Hprice effect; thus, the discouragement of ownership effect embodied in the probability of ownership variables dominates at all house prices.

To contrast our results with those in the literature, we estimated a model omitting household specific random effects and the probability of home ownership variables (Table 6). We find that the coefficient of Hprice is now negative and significant as in Engelhardt (1994). For a one standard deviation increase in Hprice, real wealth falls by $\$ 650$. If we include household specific random effects, the coefficient of Hprice is still negative, but smaller, and is marginally significant ( $t$ ratio is 1.8 ).

The coefficient of the Gift variable is 0.94 , thus households receiving a gift of greater than $\$ 100$ add nearly the entire gift to wealth ("spending" the gift on a down payment adds to wealth). The real capital gain variable for home owners has a coefficient of 0.80 , indicating some conversion of real housing gains into consumption ( 20 cents per 
dollar gain) over an average three-year period. The coefficient of the cumulative change in the real mortgage balance is -0.53 , indicating a greater offset ( 47 cents). ${ }^{28}$

The impact of marriage requires evaluating four coefficients (Marry, SumMarry, Spouse Age and HGC). The estimated wealth of a white male respondent age 26 with 12 years of education married for one year to a similar spouse is $\$ 15,500$. In contrast, the same youth, but unmarried, has wealth of $\$ 8640$. This large impact is expected because the wealth of two individuals is combined upon marriage and married couples wish to use the wealth as home equity rather than consuming it.

The impact of age on real wealth is also large. A married white respondent of age 26 has just over half the wealth of one age $32(\$ 15,500$ versus $\$ 27,810)$. A similar result occurs for an unmarried youth comparing age 26 with $32(8,640$ versus $\$ 14,060)$. Also, the impact of more education is positive as expected. Comparing a married white couple with husband and wife age 26 and educated for 12 years to a household where both have 16 years of education but are otherwise similar, we find wealth is $\$ 3,600$ greater.

\section{Summary of Findings}

The literature on tenure choice has shown household wealth to be highly correlated with home ownership. This result is not surprising given that home owners must accumulate sufficient wealth to meet market imposed down payment requirements, default insurance fees, and other closing costs and wish to accumulate additional wealth because marginal borrowing costs on high LTV loans are high (see note 4). Our focus is on the factors affecting the accumulation of wealth.

A descriptive analysis of a 1985-90 panel data set of U.S. youth age 20-27 (in 1985) suggests that the desire for home ownership is an important determinant of real wealth accumulation. Thus we anticipated that the greater is this desire, the shorter will be the expected duration until purchasing a home and the greater would be real wealth. In the econometric analysis of household wealth, we include estimates of the squared 
probability of current home ownership and the level of the five-year forward probability. We find these variables to be very significant and their impact on real wealth to be strong and highly nonlinear.

The small literature on the relationship of wealth to real constant-quality house prices has found various results ranging from dominance of a discouragement effect ("consumption of despair") to a positive relationship. We argue that spatial and intertemporal variations in real house prices may affect both the probability of home ownership and the quantity of housing demanded. We find that increases in real constantquality house prices reduce the probability of ownership, thus reducing real wealth. This result agrees with that of Yoshikawa and Ohtake (1989) for Japan and Engelhardt (1994) for Canada. We also test for a price effect on the quantity of housing demanded if ownership probability is held constant. Increased house price raises respondents' wealth (consistent with an inelastic demand for housing) more for whites than blacks. This result differs from Engelhardt but generally agrees with Y-O.

Overall, we find that variations in real constant-quality house prices have a significant net effect on the real wealth accumulation of youth. For white respondents, the relationship of wealth and real house price has an inverse U-shape, peaking near the mean house price. For black respondents, there is little variation of wealth for house prices below the mean; thereafter, wealth falls with increasing house prices.

We find that many other socio-economic and demographic variables affect the wealth of youth. Significant effects are noted for gender, age, highest grade completed, analytical aptitude, and marital status. These variables affect wealth both directly and indirectly through the probability of home ownership. 


\section{REFERENCES}

ACCRA (formerly American Chamber of Commerce Researchers Association). 1987. Cost of Living Index, Louisville, $\mathrm{KY}$.

Artle, R. and P. Varaiya. 1978. "Life Cycle Consumption and Homeownership," Journal of Economic Theory, 18: 35-58.

Buser, Steven and Anthony Sanders. 1983. Tenure Decisions Under a Progressive Tax Structure. AREUEA Journal. 11: 371-81.

Center for Human Resource Research. 1993. NLS Handbook, Ohio State University.

Engelhardt, Gary. 1994. House Prices and the Decision to Save for Down Payments. Journal of Urban Economics. 36(2): 209-37.

Gale, William, and John Karl Scholz. 1994. Intergenerational Transfers and the Accumulation of Wealth. Journal of Economic Perspectives. 8(4): 145-60.

Green, Richard. 1996. Should the Stagnant Home Ownership Rate by a Source of Concern? Regional Science and Urban Economics, June.

Greene, William. 1995. Limdep, Version 7.0 User's Manual. Econometric Software Inc. Bellport, N.Y.

Haurin, Donald, Patric Hendershott, and Susan Wachter. 1996. Wealth Accumulation and Home Ownership Rates of Young Households. Journal of Housing Research, 7(1).

Haurin, Donald, Patric Hendershott, and Dongwook Kim. 1994. Housing Decisions of American Youth. Journal of Urban Economics. 35: 28-45.

Jianakoplos, Nancy, Paul Menchik, and F. Owen Irvine. 1989. Using Panel Data to Assess the Bias in Cross-Sectional Inferences of Life-Cycle Changes in the Level and Consumption of Household Wealth. In R. Lipsey and H. Tice (eds.) The measurement of savings, investment, and wealth. National Bureau of Economic Research, Studies in Income and Wealth, Vol. 52. Chicago: Univ. of Chicago Press.

Jones, Lawrence. 1989. Current Wealth and Tenure Choice. AREUEA Journal. 17(1): 1740.

Linneman, Peter and Susan Wachter. 1989. The Impacts of Borrowing Constraints on Home ownership. AREUEA Journal. 17(4): 389-402.

Litzenberger, R. and H. Sosin. 1978. Taxation and the Incidence of Home ownership Across Income Groups. Journal of Finance. 33: 947-61. 
Mayer, Chris and Gary Engelhardt. 1994. Gifts, Down Payments, and Housing Affordability. Working Paper. Federal Reserve Bank of Boston.

McMahon, Walter. 1991. Geographic Cost of Living Differences: An Update. AREUEA Journal. 19(3): 426-50.

Rosen, Harvey S. 1979. Owner Occupied Housing and Federal Increase Tax: Estimates and Simulations. Journal of Urban Economics. 6: 247-266.

Sheiner, Louise. 1995. Housing Prices and the Savings of Renters. Journal of Urban Economics.

Yoshikawa, Hiroshi and Fumio Ohtake. 1989. An Analysis of Female Labor Supply, Housing Demand, and the Saving Rate in Japan. European Economic Review. 33: 997 1030 .

Zorn, Peter. 1989. Mobility-Tenure Decisions and Financial Credit: Do Mortgage Qualification Requirements Constrain Home ownership? AREUEA Journal. 17(1): 1-16. 


\section{ENDNOTES}

${ }^{1}$ The stagnant U.S. home ownership rate since 1980 has led to calls for Federal actions to lower this requirement (e.g., in the fall of 1994, the Clinton Administration proposed zero down payment loans). However, Green's analysis (1996) suggests that underwriting standards are not responsible for the stagnant aggregate rate in the 1980 s. In 42 of 50 states, the ratio of house prices to income declined, and in 47 states the ratio of housing expenses to income fell.

${ }^{2}$ Unexpected gifts and real capital gains change wealth exogenously (but can be offset).

${ }^{3}$ Rosen (1979) suggests an elasticity of about -0.7 .

${ }^{4}$ Households have an incentive not only to make the minimum down payment, but to make a 20 percent down payment. Generally private mortgage insurance is required on loans with less than 20 percent down, and the one-third percentage point extra charge on 10 percent down loans is applied to the entire loan balance. If the loan rate on an $80 \%$ loan is $8 \%$ and on a $90 \%$ loan is $8.34 \%$, the marginal rate being charged on the last $10 \%$ is $11 \%($ solve $80(8)+10(x)=90(8.34)$ for $x)$.

5. They ignore the negative effect of increased house price on housing demand. Unless demand is inelastic, higher house prices will lower the required down payment.

${ }^{6}$ While real rents tend to be higher in high real house price areas, the ratio still rises.

${ }^{7}$ A larger effect is obtained when the price/income ratio is used, but this reflects the effect of low real income, not low real house prices.

${ }^{8}$ The preferred sample would be renters plus the first year (or two) of home ownership. This would require significantly more complex panel data estimation owing to the variation in the length of individual panel members.

9 Renting is optimal, possibly for their lifetime, for low income households because landlords' tax benefits (reflected in the rent) exceed those that they can obtain as owners.

${ }^{10}$ For inframarginal renters, these variations have no impact.

11 The user cost approach requires an estimate of income to calculate marginal and tenure choice tax rates; however, income is clearly endogenous for young households given that they select labor supply.

12 The quality of the data was discussed in H-H-W (1995). In general, its reliability appears good.

${ }^{13}$ The number of local area CPIs is limited, thus using state data allows all observations to remain in the sample. The population weighted mean price index is: 1985=100, $1986=102.5,1987=105.4,1988=108.6,1989=112.0$, and $1990=113.9$. 
${ }^{14}$ In the NLSY data set, reported wealth is truncated to protect privacy. Because we delete households with wealth exceeding the truncation points from our sample, the wealth profiles are not overly influenced by a few extraordinarily wealthy households.

${ }^{15}$ Reading down a column yields a cross-sectional snapshot of wealth for households age $20-28$ in $1985,21-29$ in 1986 , etc.

${ }^{16} \mathrm{H}-\mathrm{H}-\mathrm{W}$ also show that home ownership rates vary inversely with real house prices.

${ }^{17}$ This model was developed by Butler and Moffitt (1982). Technical details concerning the maximum likelihood estimation procedure are given in the Limdep Manual, version 6.0 (p. 440).

${ }^{18} \mathrm{Age}$ of respondent and spouse is 26 and both have 12 years of education.

${ }^{19}$ The sample minimum and maximum Hprice observations occur at two s.d. and three s.d. from the mean.

${ }^{20}$ If 1985 owners are excluded, we systematically omit respondents who successfully saved and purchased a home. The residual sample consists of 20-27 year old youth who failed to become owners; thus, no effect of age on eventual ownership is found. Lacking any age effect on the tendency to own yields the improbable conclusion that 1990 ownership rates are similar to 1985 rates. Inclusion of 1985 owners solves this problem.

${ }^{21}$ We use a tobit model to forecast gifts and a probit model for marriage.

${ }^{22}$ The estimation procedure is generalized least squares (Greene, 1996, p. 299).

${ }^{23}$ The coefficient of the Age variable differed little from zero.

${ }^{24}$ During the $1985-90$ period, the secondary market generally required 5 percent down plus a 1.5 percent first year insurance premium. FHA required 3 to 5 percent down plus a largely borrrowable 3.8 percent up-front insurance premium. Closing costs and escrow accounts are another one to two and a half points for high LTV loans (FHA borrowers could borrow most of the closing costs).

${ }^{25}$ The longer the household is post ownership, the easier it is to offset the decline in real mortgage debt via home equity loans or refinancing.

${ }^{26}$ This result assumes that the Freddie/Fannie repeat sales price index and our crosssectional scaling of this index is accurate for locations occupied by black households.

${ }^{27}$ For our married white 26 year old, estimated wealth at various Hprices from two standard deviations below mean Hprice to two above is $(\$ 13,600, \$ 15,230, \$ 15,500$, $\$ 14,370$, and $\$ 12,870$ ).

${ }^{28}$ Other coefficients are relatively unchanged by the omission of the mortgage variable. 
Table 1: Real Household Wealth by Respondent's Age, Longitudinal Profile: 1985-90.

\begin{tabular}{|l|c|c|c|c|c|c|c||}
\hline $\begin{array}{c}\text { Age } \\
\text { in } \\
1985\end{array}$ & \multicolumn{7}{|c||}{ Real Wealth } \\
\cline { 2 - 8 } & 1985 & 1986 & 1987 & 1988 & 1989 & 1990 & $\begin{array}{c}\text { Sample } \\
\text { Size }\end{array}$ \\
\hline 20 & 3410 & 3198 & 5332 & 8519 & 10005 & 12224 & 525 \\
\hline 21 & 4136 & 4992 & 7082 & 8917 & 10065 & 15672 & 774 \\
\hline 22 & 4586 & 5332 & 8339 & 10654 & 13258 & 16213 & 741 \\
\hline 23 & 6262 & 7784 & 12937 & 15852 & 17018 & 19304 & 721 \\
\hline 24 & 8875 & 8915 & 11849 & 13428 & 15670 & 19440 & 670 \\
\hline 25 & 9607 & 10220 & 14977 & 16114 & 20847 & 24118 & 605 \\
\hline 26 & 12032 & 12472 & 16714 & 22251 & 23051 & 24134 & 555 \\
\hline 27 & 17072 & 16764 & 22297 & 24435 & 28273 & 32759 & 544 \\
\hline 28 & 17673 & 20744 & 21016 & 24811 & 31852 & 38798 & 119 \\
\hline \hline Mean & 9295 & 10047 & 13394 & 16109 & 18893 & 20358 & \\
\hline \hline
\end{tabular}

Table 2: Inter-Cohort Age-Constant Comparison of Real Household Wealth: 1985-90.

\begin{tabular}{||l|l|l|l|l|l|l||}
\hline $\begin{array}{l}\text { Constant } \\
\text { Age }\end{array}$ & \multicolumn{6}{l|l||}{$\begin{array}{l}\text { Real } \\
\text { Wealth }\end{array}$} \\
\cline { 2 - 7 } & 1985 & 1986 & 1987 & 1988 & 1989 & 1990 \\
\hline \hline 22 & 4586 & 4992 & 5332 & --- & --- & --- \\
\hline 23 & 6262 & 5332 & 7082 & 8519 & --- & --- \\
\hline 24 & 8875 & 7784 & 8339 & 8917 & 10005 & --- \\
\hline 25 & 9607 & 8915 & 12937 & 10654 & 10065 & 12224 \\
\hline 26 & 12032 & 10220 & 11849 & 15852 & 13258 & 15672 \\
\hline 27 & 17072 & 12472 & 14977 & 13428 & 17018 & 16213 \\
\hline 28 & 17673 & 16764 & 16714 & 16114 & 15670 & 19304 \\
\hline \hline
\end{tabular}


Table 3: Mean Real Household Wealth by Eight Categories of Ownership History: 1985-1990.

\begin{tabular}{||l|l||l|l|l|l|l|l||l||}
\hline Year & \multicolumn{9}{|l|}{$\begin{array}{l}\text { Real } \\
\text { Wealth }\end{array}$} \\
\cline { 2 - 10 } & $\begin{array}{l}\text { Renter } \\
1985-90\end{array}$ & $\begin{array}{l}\text { Owner } \\
1990\end{array}$ & $\begin{array}{l}\text { Owner } \\
1989\end{array}$ & $\begin{array}{l}\text { Owner } \\
1988\end{array}$ & $\begin{array}{l}\text { Owner } \\
1987\end{array}$ & $\begin{array}{l}\text { Owner } \\
1986\end{array}$ & $\begin{array}{l}\text { Owner } \\
1985\end{array}$ & Other \\
\hline \hline 1985 & 3326 & 4121 & 5578 & 6742 & 10290 & 12714 & $\mathbf{2 9 6 1 5}$ & 14834 \\
\hline 1986 & 3082 & 4389 & 4911 & 8465 & 12103 & $\mathbf{1 8 7 2 1}$ & 31193 & 16157 \\
\hline 1987 & 4607 & 6387 & 9514 & 11412 & $\mathbf{2 8 7 8 5}$ & 30853 & 39112 & 19070 \\
\hline 1988 & 5510 & 8635 & 12900 & $\mathbf{2 8 5 1 3}$ & 30596 & 35761 & 43354 & 20241 \\
\hline 1989 & 6531 & 12563 & $\mathbf{2 6 4 4 2}$ & 35420 & 36411 & 40804 & 46423 & 20976 \\
\hline 1990 & 8297 & $\mathbf{2 6 1 8 3}$ & 29554 & 46158 & 37615 & 46507 & 54021 & 19401 \\
\hline \hline Mean & 5226 & 10380 & 14817 & 22785 & 25967 & 30893 & 40620 & 18447 \\
\hline
\end{tabular}

Table 4: Renters' Mean Real Wealth by Three Levels of Aptitude Test Score and Four Categories of Real Constant-Quality House Price: 1985 Distribution of House Prices

\begin{tabular}{|c|c|c|c|c|}
\hline & \multicolumn{4}{|c|}{$\begin{array}{l}\text { Renters' } \\
\text { Real Wealth } \\
\text { for Three } \\
\text { Levels of } \\
\text { Aptitude } \\
\text { Test Score } \\
\end{array}$} \\
\hline & \multicolumn{4}{|c|}{1985 Constant-Quality House Price Quartiles } \\
\hline Year & Lowest $25 \%$ & $\begin{array}{c}25 \%- \\
50 \%\end{array}$ & $50 \%-75 \%$ & Highest 25\% \\
\hline Mean-top third & 8786 & 11726 & 11582 & 7535 \\
\hline Mean-middle third & 5959 & 5504 & 10809 & 6855 \\
\hline Bottom third & 3095 & 3054 & 3649 & 3232 \\
\hline All Renters & 5827 & 6347 & 8461 & $\overline{c 5718}$ \\
\hline
\end{tabular}


Table 5: Panel Data Probit Estimation of the Probability of Owning a Home Currently

\begin{tabular}{|c|c|c|c|}
\hline Explanatory Variable & Coefficient & $\begin{array}{c}\text { Standard } \\
\text { Error }\end{array}$ & Mean \\
\hline Male & 0.110 & $0.007^{ \pm+}$ & 0.45 \\
\hline Black & -0.458 & $0.116^{\star \star}$ & 0.26 \\
\hline Married & -1.100 & $0.076^{ \pm \star}$ & 0.41 \\
\hline Hprice & 0.012 & $0.002^{\star \star}$ & 87.17 \\
\hline Age & -0.165 & $0.007^{\star \star \star}$ & 26.23 \\
\hline HGC & -0.230 & $0.010^{\star \star}$ & 13.00 \\
\hline Spouse-Age & 0.109 & $0.004^{\star \star}$ & 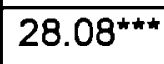 \\
\hline Spouse-HGC & 0.050 & $0.009^{\star \star}$ & $12.93^{\star \star \star *}$ \\
\hline Aptitude & 0.014 & $0.001^{\star \star}$ & 45.35 \\
\hline Gifts & -0.027 & $0.009^{* \star}$ & 0.25 \\
\hline Squared Hprice & -0.00013 & $0.00001^{\star k}$ & 8081.7 \\
\hline Squared Age & 0.00534 & $0.00023^{\text {\#\# }}$ & 328.96 \\
\hline Squared HGC & -0.00802 & $0.00038^{\star \star}$ & 173.88 \\
\hline Squared Aptitude & -0.00007 & $0.00001^{* \pm}$ & 2891.8 \\
\hline Squared Spouse-Age & -0.00160 & $0.00006^{* \pm}$ & 328.96 \\
\hline Squared Spouse-HGC & -0.00173 & $0.00035^{\star \star}$ & 70.20 \\
\hline Hprice*Age & 0.00027 & $0.00007^{\star \star}$ & 2294.4 \\
\hline Hprice*Black & -0.00066 & 0.00043 & 22.97 \\
\hline Hprice*Marry & 0.00040 & 0.00038 & 35.24 \\
\hline Hprice*Gifts & 0.00050 & $0.00011^{\text {k\# }}$ & 20.71 \\
\hline Black*HGC & 0.066 & $0.005^{\star \star}$ & 3.34 \\
\hline Black*Age & -0.030 & $0.003^{\star \star *}$ & 6.89 \\
\hline Black ${ }^{\star}$ Marry & -0.278 & $0.019^{* *}$ & 0.59 \\
\hline Rho & 0.884 & $0.001^{\star *}$ & \\
\hline
\end{tabular}

$N=6324: 1064$ respondents for 6 years. Wealth, Gifts, and Hprice are measured in thousands of dollars. Log-Likelihood $=-1778.1$; Slopes $=0$ log-likelihood $=-2481.5$. *Significant at $0.05 ;{ }^{* \star}$ Significant at $0.01 ;{ }^{* \star \star}$ Mean is for married respondents, singles have the spouse variables set to 0 . 
Table 6: Random Effects and Simple Pooled Data Estimation of Household Wealth

\begin{tabular}{|c|c|c|c|c|c|c|c|}
\hline $\begin{array}{c}\text { Explanatory } \\
\text { Variable }\end{array}$ & Coefficient & $\begin{array}{c}\text { Standard } \\
\text { Error }\end{array}$ & Coefficient & $\begin{array}{c}\text { Standard } \\
\text { Error }\end{array}$ & Coefficient & $\begin{array}{c}\text { Standard } \\
\text { Error }\end{array}$ & Mean \\
\hline & \multicolumn{2}{|c|}{$\begin{array}{c}\text { Random Effects } \\
\text { Model }\end{array}$} & \multicolumn{2}{|c|}{$\begin{array}{c}\text { Simple Pooled Data } \\
\text { Model }\end{array}$} & \multicolumn{2}{|c|}{$\begin{array}{l}\text { Reference Simple } \\
\text { Pooled Data Model }\end{array}$} & \\
\hline Constant & \begin{tabular}{|l|}
29.09 \\
\end{tabular} & $6.38^{\star \star}$ & 14.69 & $5.94^{* \star}$ & 21.23 & 5.93 & \\
\hline Male & 1.79 & $0.75^{\text {tఓ }}$ & 1.97 & $0.41^{\star \star *}$ & 2.78 & $0.41^{\text {t"t }}$ & 0.45 \\
\hline Black & 1.31 & 2.55 & 1.32 & 2.11 & -4.13 & $0.51^{\star \star}$ & 0.26 \\
\hline Married & -11.94 & $2.90^{k \star}$ & -17.93 & $2.61^{\star \star}$ & -23.80 & $2.57^{\text {th }}$ & 0.41 \\
\hline SumMarry & 0.70 & $0.18^{\text {w* }}$ & 0.43 & $0.19^{\star}$ & 0.75 & $0.19^{\text {t* }}$ & 1.32 \\
\hline HGC & -2.89 & $0.51^{\text {\#* }}$ & -1.67 & $0.46^{\text {*t" }}$ & -2.21 & $0.46^{\text {\#\# }}$ & 13.00 \\
\hline Spouse-Age & 0.23 & $0.09^{\star \star}$ & 0.40 & $0.08^{* \star}$ & 0.67 & $0.07^{\star \star}$ & $28.08^{* * *}$ \\
\hline Spouse-HGC & 0.65 & 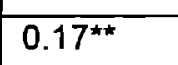 & 0.69 & $0.15^{\star \star}$ & 1.05 & $0.15^{\text {tht }}$ & $12.93^{ \pm+*}$ \\
\hline Aptitude & 0.11 & $0.05^{\star}$ & 0.06 & $0.03^{\star}$ & 0.12 & $0.03^{\text {*t }}$ & 45.35 \\
\hline Gift & 0.94 & $0.10^{ \pm \star}$ & 1.57 & $0.12^{\star \star}$ & 1.68 & $0.12^{\text {nᄎ }}$ & 0.25 \\
\hline Squared Age & -0.052 & $0.008^{* *}$ & -0.036 & $0.008^{*}$ & -0.033 & $0.008^{\star \star}$ & 696.08 \\
\hline Squared Aptitude & -0.0009 & 0.0005 & -0.0007 & $0.0003^{\text {** }}$ & -0.0008 & $0.0003^{\text {\# }}$ & 2891.8 \\
\hline Squared Age*HGC & 0.0048 & $0.0006^{\star \star}$ & 0.0033 & $0.0006^{\star \star}$ & 0.0039 & $0.0006^{* \star}$ & 341.62 \\
\hline Squared Probown & 19.28 & $2.50^{\star \star t}$ & 25.45 & $2.36^{ \pm \star}$ & --- & $\begin{array}{ll}--- \\
\end{array}$ & 0.13 \\
\hline Probown5 & 4.33 & $0.21^{\text {kt }}$ & 8.04 & $2.21^{\text {\#\# }}$ & --- & --- & 2.37 \\
\hline Hprice & 0.037 & $0.019^{\star}$ & 0.046 & $0.017^{\star}$ & -0.030 & $0.009^{* *}$ & 3.52 \\
\hline Hprice ${ }^{*}$ Black & -0.041 & 0.026 & -0.029 & 0.022 & --- & ---- & 22.51 \\
\hline Capital Gain & 0.80 & $0.03^{\text {** }}$ & 0.85 & $0.03^{\star \star}$ & 0.88 & $0.03^{\# \star}$ & 0.84 \\
\hline DiffGain & -1.0 & ---- & -1.0 & --- & -1.0 & $\begin{array}{c}--- \\
\end{array}$ & \\
\hline Mortgage & -0.53 & $0.03^{\text {t* }}$ & -0.64 & $0.04^{\star * t}$ & -0.65 & $0.04^{\star \star}$ & -0.11 \\
\hline
\end{tabular}

$N=6324: 1064$ respondents for 6 years. Wealth, Gifts, Hprice, Capital Gains, and Mortgage are measured in thousands of dollars.

*Significant at $0.05 ;$ **Significant at 0.01 .

***Mean is for married respondents, singles have the spouse variables set to 0 .

${ }^{* \pm *+C}$ Cumulative from date of purchase or 1985.

Adjusted $R$-squared $=0.40,0.39,0.38$ respectively.

Lagrange Multiplier Test of no household specific random effects $=4415,1$ d.f., significant at 0.01 . 
Appendix 1: Asset Category Definitions and Truncation Points in the NLSY and SCF Data Sets

The truncation points are the same in each year of the survey. Truncation is applied independently in each category. A respondent with a truncated value in any category is deleted from the sample.

1. Liquid Assets: sum of cash, savings \& checking accounts, funds in money market and credit unions, U.S. savings bonds, IRAs, Keoghs, certificates of deposit, personal loans to others [truncated if $>\$ 500,000$ ].

2. Mutual and Investment Funds: sum of value of common stock, preferred stock, stock options, corporate bonds, government bonds, mutual funds [truncated if $>\$ 500,000$ ] <and> value of rights to an estate or investment trust [truncated if $>\$ 500,000]$.

3. Net Value of Durables: value of motor vehicles including cars, trucks, motorcycles, motor homes [truncated if $>\$ 30,000$ ] <less> debt on motor vehicles [truncated if > $\$ 30,000$ ] <and> value of other durables (each worth more than $\$ 500$ ) including furniture, appliances, boats, jewelry, stereo, collections [truncated if $>\$ 150,000$ ] <less> other debts including those to stores, doctors, hospitals, banks, or other people [truncated if $>\$ 150,000]$.

4. Value of investment in a farm, business, or professional practice [truncated if $>\$ 500,000$ ] $<$ less $>$ debts on farm, business, professional practice [truncated if $>\$ 500,000$ ].

5. House Value (home owners only) [truncated if $>\$ 150,000$ ].

6. Sum of mortgage, back taxes, home improvement loans (home owners only) [truncated if > $\$ 150,000]$. 
Appendix 2: Table A-1: Cross-sectional Data Probit Estimation of the Probability of Owning a Home in Five Years

\begin{tabular}{|c|c|c|c|}
\hline Explanatory Variable & Coefficient & Standard Error & Mean \\
\hline Male & -0.04 & 0.10 & 0.45 \\
\hline Black & -0.26 & 2.29 & 0.26 \\
\hline Married-predicted & 8.29 & 4.46 & 0.50 \\
\hline Hprice & 0.050 & 0.035 & 77.42 \\
\hline Age & -0.207 & $0.181^{*}$ & 23.73 \\
\hline HGC & -0.389 & 0.379 & 12.82 \\
\hline Aptitude & -0.014 & 0.013 & 45.35 \\
\hline Gift-predicted & 1.40 & 1.69 & 0.34 \\
\hline Squared Hprice & 0.0001 & 0.0001 & 6238.8 \\
\hline Squared Age & 0.0045 & 0.0052 & 568.26 \\
\hline Squared HGC & 0.0202 & 0.0194 & 168.64 \\
\hline Squared Aptitude & 0.0001 & 0.0001 & 2891.8 \\
\hline Hprice Age & -0.0026 & 0.0020 & 1837.7 \\
\hline Hprice*Black & 0.002 & 0.047 & 19.70 \\
\hline $\begin{array}{l}\text { Hprice*Marry- } \\
\text { predicted }\end{array}$ & -0.023 & 0.017 & 39.46 \\
\hline Hprice ${ }^{\star}$ Gift-predicted & -0.010 & 0.017 & 26.21 \\
\hline Black*HGC & -0.020 & 0.081 & 3.30 \\
\hline Black ${ }^{\star}$ Age & 0.070 & 0.084 & 6.23 \\
\hline Black"Marry-predicted & -1.53 & 2.70 & 6.23 \\
\hline $\begin{array}{l}\text { Probability of } \\
\text { Own in } 1985\end{array}$ & 2.72 & $0.37^{\text {tk }}$ & $\overline{0.17}$ \\
\hline
\end{tabular}

$\mathrm{N}=1064$. Wealth, Gifts, and Hprice are measured in thousands of dollars.

*Significant at 0.05 ; " Significant at $0.01 ;{ }^{* \star *}$ Mean is for married respondents, singles have the spouse variables set to 0 .

Log-Likelihood $=-562.3$ Chi-squared ( 1 d.f.) test of slopes $=0$ is 244.0. 